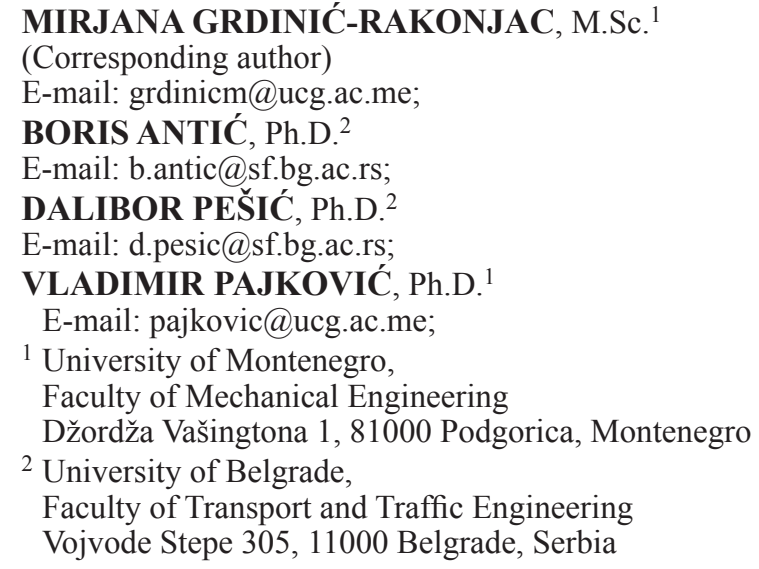

\title{
CONSTRUCTION OF ROAD SAFETY COMPOSITE INDICATOR USING GREY RELATIONAL ANALYSIS
}

\begin{abstract}
Aggregation of different variables into one road safety performance index is a popular concept in evaluating road safety and comparing the performance of territories/entities. This paper presents the development of a novel and innovative weighting methodology using grey relational analysis. Based on the proposed model, ten hierarchical road safety indicators were selected in terms of a two-layered model with three categories related to behaviour, safety and system. Grey weights are assigned to the categorized indicators in each layer, and the grey road safety composite indicator for each entity (21 selected territories) is calculated by the weighted sum approach. With relatively high weights, this systematic methodology can serve the policy makers in targeting the risk domains where improvements are needed. The results clearly illustrate effectiveness in addressing a large number of indicators with hierarchical structures.
\end{abstract}

\section{KEYWORDS}

road safety; composite indicator; weighting method; grey relational analysis; grey weights; case study.

\section{INTRODUCTION}

According to the WHO [1], one of the leading causes $\left(6^{\text {th }}\right.$ place $)$ of death by injury are road traffic injuries, with nearly 3,700 people killed every day. Because of this basic problem, halving the number of road accidents and injuries by 2020 was set as a target endorsed by the Council of the European Union in 2010 [2], the Decade of Action for Road Safety launched in May 2011 [3], and the Sustainable Development Goals published in 2015 by the
United Nations [4]. In addition, as reported by the WHO [1], 132 countries enacted funded national strategies for road safety, and 109 countries set national goals for the reduction of road deaths. In Montenegro, one of the developing West Balkan countries that is attempting to fulfil the rules and regulations of the EU by relying on these EU and UN programs, the National Coordination Board and its government adopted the Strategy for improvement of road traffic safety 2010-2019 [5] and the Action plan for Strategy [6] with the goal of reducing fatalities by $50 \%$ and injuries by $30 \%$ (compared with 2007) by 2019. Although most of the countries that participate in the actions adopted by the EU and UN have road traffic laws that meet the criteria of best practices for most risk factors, at this point, the goal does not appear to be achieved. A large increase in road safety was recorded in the first years of the strategies, but the number of 25,100 people killed in road accidents in 2018 in the European Union [7] means a 21\% decrease in the number of road deaths compared with 2010 when 31,500 road deaths were recorded [8]. This fact indicates that the situation has not improved in the last few years because there are seemingly no effective prevention and sustainable measures against it. Statistics from the USA and EU generally show certain progress but stagnation in recent years. However, data from Montenegro show a deficiency in road safety performance. One way to improve the road safety status is to learn from more successful examples. To compare 
road safety level with others, a composite index should be constructed that evaluates traffic safety level on a territory and reflects all of road safety-related information. Recently, many authors have addressed this challenging subject. No universal approach exists between countries, which consequently results in a large number of methods for index development and benchmarking of road safety. An additional problem are the different types of data collected by different countries, especially the undeveloped countries such as Montenegro, which do not have the same laws and do not yield the same regulations as the developed countries. In this paper, grey weights are calculated for each indicator within three categories and for each layer of a two-layer hierarchy situation. The composite indicator is determined by the weighted sum approach. An illustrative example of the application of this method is presented, namely, a case study in constructing the grey road safety composite indicator. The scores of the territories and the weights assigned to each layer of hierarchy are analysed, followed by comparison of the results with those from the one-layer situation.

The structure of this paper is described as follows. In the next section, examples from the literature that address the construction of a composite index are presented. An overview of the theory behind the applied weighting methodology is presented in Section 3. The selection of the used indicators is briefly described following a presentation of the data used in numerical examples, and finally, in Section 5, the results of the novel methodology implementation are presented together with the Montenegro case study. The paper ends with conclusions and future research on this subject.

\section{LITERATURE REVIEW}

In this section historical evolution of addressing the construction of a road safety composite index is presented and the diversity of approaches is shown. One of the first authors to this issue was Al-Haji $[9,10]$,who suggested that for the assessment of country road safety, a master-list of indicators related to performance should be implemented and subsequently classified into several main categories, followed by combining them into one single value. One of the most important research studies was the SafetyNet project within which the theoretical assumption for road safety indicators was presented, although it did not combine the indicators into one composite value [11]. This project served as a base for further research in this field and was a component of the SUNflower project [12] in which the authors proposed grouping of territories according to their safety level and assignment of weight to each of them using principal component and factor analysis to create an overall safety index.

Hermans et al. [13] combined the indicators in one performance indicator by assigning the weights to each and used five weighting methods that were applied to the road safety data from various countries. This effort resulted in a discussion of the advantages and disadvantages of each, and finally obtained one method that was justified. In 2008, the European Commission and OECD published a handbook for constructing road safety composite indicators [14] and proposed the following weighting methods: weights based on principal component analysis, data envelopment analysis, analytic hierarchy process, benefit of the doubt approach, budget allocation process, unobserved components model, conjoint analysis and public opinion. These institutions also proposed different aggregation methods: additive (weighted sum approach), geometric aggregation, and non-compensatory multi-criteria aggregation. In their paper, Wegman and Oppe [15] sought to outline the development of a benchmarking standard, and they created a framework for composing one safety index related to a set of the following indicators: outcome indicator that represents the number of people killed and injured in road accidents, indicator that represents the road safety policy implementation quality, and a final indicator related to the response to those implemented policies.

Gitelman et al. [16] proposed a composition of a road safety index by combining the basic indicators using weights based on the statistical models. The indicators used in the Gitelman paper were grouped into those related to policy performance, final safety outcomes (fatality and injury rates), intermediate outcomes (rates of wearing seat belts, vehicle fleet composition and driving under the influence of alcohol) and characteristics of countries (motorization and population). Pešić et al. [17] introduced the benchmarked traffic safety level index, the so called BTSL, derived from safety performance indicators (fatalities, seat belt use, driving under the influence of alcohol, speeding) and three outcome indicators (public, traffic and dynamic traffic risk). 
The BTSL results in a single value that enables a defined safety level for a territory and comparison with a similar value.

In their paper, Kukić et al. [18] gave a critical review of the methods for road safety comparison and showed an example of selecting a relevant indicator model that is based on final outcomes in the chosen countries in Europe. Additionally, the paper represented a map of the chosen EU territories according to casualty risk. Tešić et al. [19] composed a road safety performance index that included a limited number of indicators but still gave a quality comparison of as many entities as possible. The Tešic group used the indicators related to alcohol, speed and protective systems and those related to roads and management of trauma. Composition of one road safety indicator is currently receiving increased attention in the literature as well as the use of various methodologies for that purpose. Therefore, it is surprising that few studies in literature use grey relational analysis in this effort.

Grey Relational Analysis (GRA) is a multidisciplinary tool and it is successfully used in various fields such as economics, management, decision-making, medicine, prediction, modelling, and data processing, among others. With respect to road safety, Lu and Wevers [20] used the grey relational methodology for the evaluation of road safety in urban roads in the Netherlands and used GRA to rate the scenarios of infrastructure, advanced driver assistance systems and their combinations, which are expected to be implemented to improve road safety. Ma et al. [21] used a combination of the grey and fuzzy theory to create three different sets of composite road safety indicators by considering judgment attitudes: one related to regional roads, one related to urban roads and one related to highways. René et al. [22] applied the grey system with time series to predict the expected number of accidents and relayed results to target the improvement that should be performed and measures that should be conducted. Liu et al. [23] used grey relational analysis to calculate the weights for the purpose of constructing a fuzzy road safety indicator. The evaluation of the road safety of China provinces was the goal of this particular research. The authors used nine indicators related to the frequency, severity and trend of traffic accidents and applied a fuzzy comprehensive method to obtain the final score.
According to the above mentioned Road Safety studies, where GRA was successfully implemented, for computing of the composite indicator and evaluating road safety of territory, related to this particular research, a novel methodology integrating Grey Relational Analysis (GRA) is proposed.

\section{METHODOLOGY}

\subsection{Grey relational analysis}

Grey theory, first proposed by Deng [24] is an effective method for the analysis of systems with partially known and partially unknown information. Grey theory operates with discrete data that are classified as black (unknown data), grey (incomplete data) or white (accurate data). In other words, it can be said that grey models predict the values of time series based only on the set of the most recent data and can be understood as curve fitting. GRA is normalization-based theory that implies positive data values and normalization data can be various. Standard normalization in grey analysis is chosen and explained below. The steps of the mathematical calculations in GRA are derived as follows:

\section{Step 1: Constructing a normalized matrix}

When data are collected, they are placed in $K$ categories and $L$ layers. Each category of indicators $(k=1, \ldots, K)$ form a matrix where indicators represent alternatives $\left(i=1, \ldots, m_{k}\right)$ and territories represent attributes $(j=1, \ldots, n)$. The decision matrix can be presented as follows:

$X_{i}=x_{i}(1), x_{i}(2), \ldots, x_{i}(j), \ldots, x_{i}(n)$

With different criteria in question, normalization must be performed. Three standard methods of normalization used in grey analysis are based on the following criteria types: nominal the best, smaller the better and larger the better. In this paper, the third rule is used in order that larger assigned weight represents greater significance of indicator:

$g_{i}(j)=\frac{x_{i}(j)-\min _{j=1}^{n} x_{i}(j)}{\max _{j=1}^{n} x_{i}(j)-\min _{j=1}^{n} x_{i}(j)}$

In addition, normalized matrix is derived as $G$ :

$G=\left[\begin{array}{ccc}g_{1}(1) & g_{1}(2) & g_{1}(n) \\ g_{2}(1) & g_{2}(2) & g_{2}(n) \\ g_{m_{k}}(1) & g_{m_{k}}(2) & g_{m_{k}}(n)\end{array}\right]$

For the purpose of constructing the grey composite indicators to evaluate the road safety of a territory, the normalized matrix is separately constructed for each category of indicators. 
Step 2: Selecting the referent set

After normalization of all values as the first step, the grey relational degree is calculated for each category as described below.

The referent data set for the normalized matrix is constructed. The referent set represents the virtual ideal set and is formed from the ideal values of attributes, maximum or minimum, depending on the research goal. In a matter in which higher weight represents a larger influence in a road safety situation, the reference set in this particular research is constructed from the maximum values.

$G_{0}=\left(g_{01}, g_{02}, \ldots, g_{0 n}\right) ;$

\section{Step 3: Computing the grey relational coefficient}

When the referent set is formed, the grey relational coefficient is calculated by measuring the distance of each indicator value from the referent set as shown in Equation 4.

$\zeta_{0 i}(j)=\frac{\Delta_{\min }+\rho \Delta_{\max }}{\Delta_{0 i}(j)+\rho \Delta_{\max }}$

where:

$$
\begin{aligned}
& \Delta_{0 i}(j)=\left|g_{i}(j)-g_{0 j}\right| \\
& \Delta_{\max }=\max _{i=1}^{m k} \max _{j=1}^{n} \Delta_{0 i}(j) \\
& \Delta_{\min }=\min _{i=1}^{m k} \min _{j=1}^{n} \Delta_{0 i}(j)
\end{aligned}
$$

where $\rho$ represents the distinguishing coefficient $[0,1]$ and usually takes on the value of 0.5 implying a moderate distinguishing effect.

\section{Step 4: Computing the grey relational degree}

When $m_{k}$ is the number of indicators in each of $K$ categories and $n$ is the number of territories (countries, regions, municipalities, etc.), the significance of each indicator in each category can be calculated via the following equation:

$$
\Gamma_{0 i}=\frac{1}{n} \sum_{j=1}^{n} \zeta_{0 i}(j)
$$

If the weights $w(j)$ for the attributes are known, then the grey relational degree can be calculated as follows:

$$
\Gamma_{0 i}=\sum_{j=1}^{n} \zeta_{0 i}(j) w(j)
$$

where the sum of the attributes weights must equal 1. Moreover, the computed relational degree is normalized with Equation 7 because it represents the input weight for further analysis.

$$
w_{\text {grey }}(i)=\frac{\Gamma_{0 i}}{\sum_{i=1}^{m k} \Gamma_{0 i}}
$$

\subsection{Construction of the grey composite indicator}

The hierarchy of the indicator groups with $L$ layers and $m^{(l)}=\sum_{k=1}^{K} m_{k}$ number of indicators in the $l$-th layer $(l=1, \ldots, L)$ as presented in Figure 1 . The calculated and normalized, grey relational degree $w_{\text {grey }}(i)$ represents the input grey weight $w_{i k}^{(l)}$ of the given indicator $i$ into the observed category $k$. When the grey weights are derived within all categories, the scores for each category and each municipality $g_{k}^{(l+1)}$ are obtained as the weighted sum of grey weights and the corresponding indicator:

$g_{k}^{(l+1)}=\sum_{i=1}^{m k} w_{i k}^{(l)} g_{i}(j)$

These scores related to each category represent a novel input matrix for the second iteration of GRA (matrix $K \times n$ ), calculating the grey weight at the next level $w_{i k}^{(l+1)}$. When all grey weights are obtained, the grey composite indicator is constructed using the additive model. The idea of the proposed model is to derive the values of a particular indicator category of a particular layer using the weighting sum approach implying that the sum of weights at every level is equal to 1 . In addition, for any observed territory, if $A_{k l}^{(l)}$ is a set of input factors (normalized values of road safety indicators and the corresponding grey

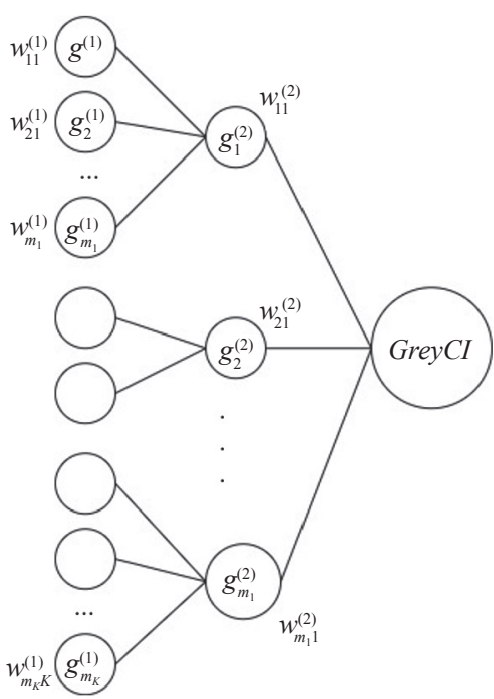

Figure 1 - Indicators hierarchy for constructing GreyCI 


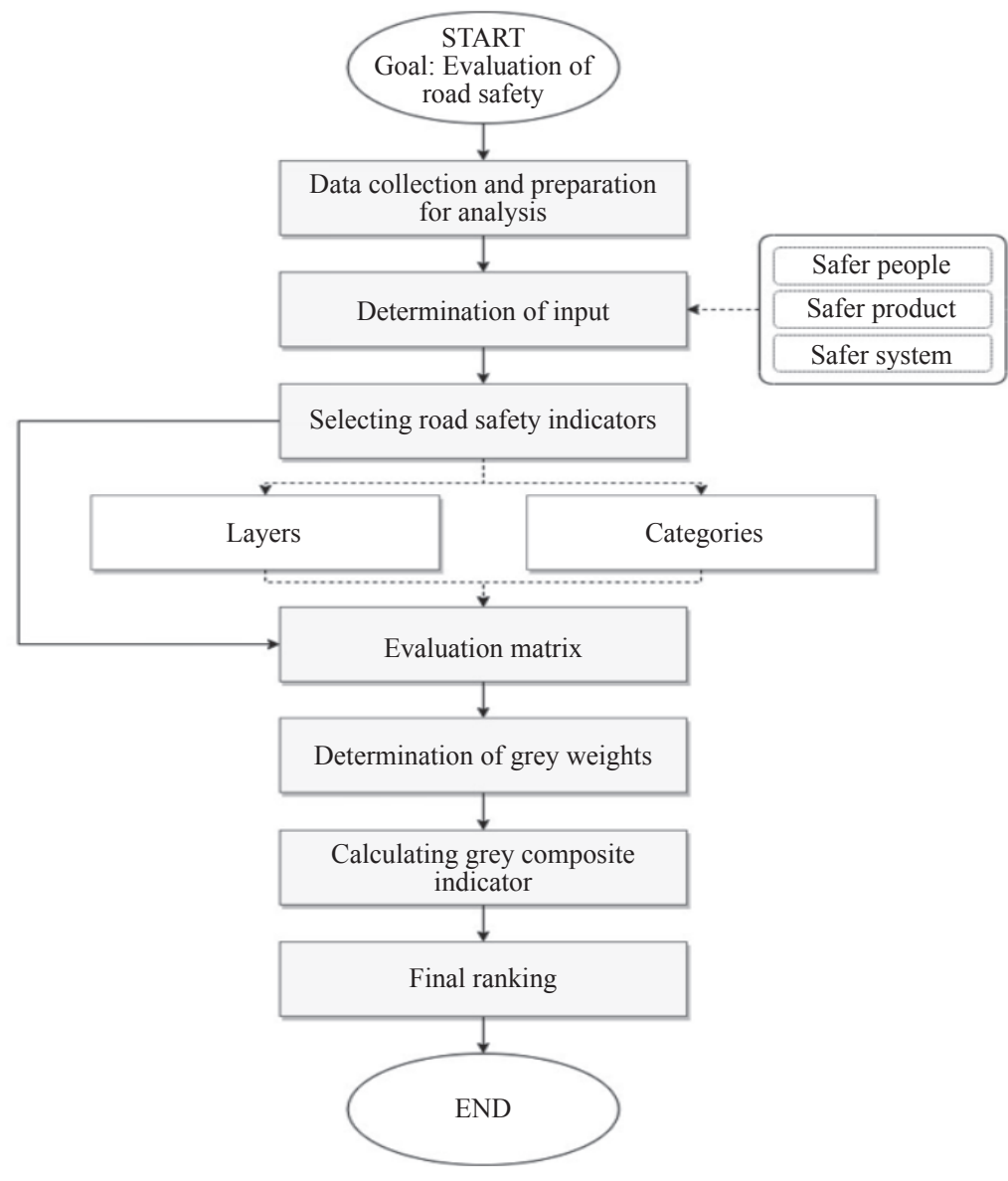

Figure 2 - Framework of the proposed methodology

weights) of the $k$-th category in the $l$-th layer, the aggregated grey composite indicator is noted as in Equation 9.

$$
\begin{aligned}
& \text { GreyCI }=\sum_{k_{L-1} \in A_{k L}^{(L)}} w_{k_{L-1}}^{(L-1)} \cdots \\
& \quad \cdots\left(\sum_{k l \in A_{k l+1}^{(l+1)}} w_{k l}^{(l)} \cdots\left(\sum_{k_{2} \in A_{k 3}^{(3)}} w_{k 2}^{(2)}\left(\sum_{k_{1} \in A_{k 2}^{(2)}} w_{k 1}^{(1)} g_{k 1}^{(1)}\right)\right)\right)
\end{aligned}
$$

where:

$$
\sum_{k l \in A_{k l+1}^{(l+1)}} w_{k l}^{(l)}=1 ; k_{l}=1, \ldots, K^{(l)}
$$

The final result for each territory is given as:

$g C I=1-$ GreyCI

with the purpose that a larger result represents a greater road safety level. The scheme of the proposed methodology is given in Figure 2 .

\subsection{Grouping territories}

The municipality scores can be compared and the one with the highest road safety level represents the benchmark municipality. However, if it is known that there are differences between territories, for policy makers it is more important to compare these with similar road safety backgrounds, identify the best-inclass and learn from it [12]. In this study, the grouping is made based on the methodology described in Chen et al. [25]. The distribution of $g C I$ is determined, following the frequencies, cumulative frequencies, percentiles and corresponding probit. The regression model is developed regarding the $g C I$ and $Y$ value as dependent and independent values, respectively.

$g C I=a+b Y$

where $a$ and $b$ are regression parameters. Using the regression model, the critical value of $g C I$ is calculated as the class interval and the corresponding percentiles and probit.

$g C I^{*}=a+b Y^{*}$

For detailed steps of the grouping see Chen et al. [25]. To ensure that the grouping is statistically significant $(P<0.01)$, the analysis of variance is performed with $95 \%$ level of confidence. Within each group, the territory with the highest $g C I$ value can be considered as benchmark territory. 


\section{CASE STUDY}

\subsection{Selected indicators}

Understanding and selecting factors that cause road traffic accidents and constructing one reliable indicator that reflects the safety situation are essential for valid scientific road safety evaluation. According to SafetyNet [26], the most important areas of road safety are speed (\% speeding), alcohol and drugs ( $\%$ driving under the influence of alcohol or drugs), infrastructure (network density), protective systems (\% non-wearing seatbelt), vehicle (number and vehicle age), visibility (\% not using daytime running lights), and trauma care (average response time). Each of the mentioned items can be observed as grey data, together with public and traffic risks that represent the number of both, accidents and fatalities per population and the number of accidents and fatalities per motorization level [27].Other frequently used items are well-known indicators such as the length of the road network, number of inhabitants, number of registered vehicles, distance travelled, etc. Depending on the choice of indicator, the compared entities might have different evaluation results. As mentioned previously, Al-Haji [10] proposed classification of all road safety-related indicators into three main groups that reflect safer product, safer people, and safer system.

With respect to the literature and availability of data, in this research three types of indicators proposed by Al-Haji $[9,10]$ and Gitelman et al. [16] are used, modified and classified into groups (see Table 1). The first group of indicators is classified as intermediate outcomes and reflects safer people. Driving above the speed limit, under the influence of alcohol and drugs and the use of a protective system are chosen in addition to using a mobile phone during driving. It should be noted that the indicators reflecting behaviour should be the rates of people wearing seatbelts, rates of driving under the influence of alcohol, etc., but in Montenegro, such data are unavailable. Therefore, to address those behaviours, the number of violations recorded by the police (data are collected from the Ministry of the Interior) is considered, as suggested by Antić et al. [28]. To describe the municipality more correctly, the number of violations is given as the rate per thousand inhabitants.

The next group of indicators used in this research reflects safer products and is referred to as the final outcome of road safety: the fatality rate presented in this work with public and traffic risks (number of fatalities per ten thousand inhabitants and number of fatalities per ten thousand vehicles, respectively) and accident rate, also presented as public and traffic risks (number of accidents with fatalities per ten thousand inhabitants and number of accidents with fatalities per ten thousand vehicles, respective1y). Cheng et al. [29] state that when accessing the traffic safety level of the territories and performing comparison, the number of fatalities per number of vehicles should be considered first. However, in this paper, all of the risk-exposure indicators are placed into one category with no preference.

The third group of indicators of the dataset reflects safer systems. The characteristics of municipalities are used, such as road density, represented as the number of kilometres of roads per square kilometre of territory, and motorization level, which is represented by the number of vehicles per thousand inhabitants. It should be mentioned that some of the influential system indicators, such as road conditions, trauma management, age of the vehicle fleet, etc., were not included in the analysis because they were unavailable for all the territories under evaluation. The final list of the selected indicators available for every territory is presented in Table 1.

\subsection{Data}

The proposed methodology is implemented in the Montenegro case study. Certain characteristics are given as follows (all data are collected from the Ministry of the Interior).

Road density and motorization rate, in 2016, were $57.2 \mathrm{~km} / \mathrm{km} 2$ and 330 cars per 1,000 inhabitants, respectively. In 2018, Montenegro recorded a decrease of $50 \%$ in road deaths compared with 2010 and a decrease of approximately $20 \%$ compared with 2011. By observing a longer period, it can be noted that road safety is in fact at a low level, with various numbers of people killed in road accidents every year. When translated into fatalities per million inhabitants, Montenegro's rate in 2018 is 77, compared with the European average of 49 and with the worst-performing EU countries, namely, Romania (98), Bulgaria (88), Latvia (78) and the neighbouring Croatia (77), [30].

In total, ten hierarchical indicators are used within two layers. The indicators were normalized via Equation 2 and the results are shown in Table 2. 
Grdinić-Rakonjac M, et al. Construction of Road Safety Composite Indicator Using Grey Relational Analysis

Table 1 - Road safety evaluation indicators

\begin{tabular}{||c|c|l|l||}
\hline Indicator group & Id & \multicolumn{1}{|c|}{ Indicators } & \multicolumn{1}{c||}{ Description } \\
\hline \hline \multirow{5}{*}{ Safer people } & I1 & Speed & $\%$ speeding \\
\cline { 2 - 5 } & I2 & Alcohol/drug & $\%$ driving under the influence of alcohol or drugs \\
\cline { 2 - 5 } & I3 & Seatbelt & $\%$ non-wearing seatbelt \\
\cline { 2 - 5 } & I4 & Mobile phone & $\%$ using mobile phone while driving \\
\hline \multirow{5}{*}{ Safer product } & I5 & Public fatality rate & Number of fatalities per ten thousand inhabitants \\
\cline { 2 - 5 } & I6 & Traffic fatality rate & Number of fatalities per ten thousand vehicles \\
\cline { 2 - 4 } & I7 & Public accident rate & Number of accidents with fatalities per ten thousand inhabitants \\
\cline { 2 - 5 } & I8 & Traffic accident rate & Number of accidents with fatalities per ten thousand vehicles \\
\hline & I9 & Road density & Number of kilometres of roads per square kilometre of territory \\
\cline { 2 - 4 } & I10 & Motorization rate & Number of vehicles per thousand inhabitants \\
\hline
\end{tabular}

Table 2 - Normalized indicators of road safety in the case study of Montenegro by municipalities

\begin{tabular}{|c|c|c|c|c|c|c|c|c|c|c|}
\hline Mun. & I1 & I2 & I3 & I4 & I5 & I6 & I7 & I8 & I9 & $\mathrm{I} 10$ \\
\hline $\mathrm{AN}$ & 0.0000 & 0.0281 & 0.1865 & 0.1828 & 0.1582 & 0.0963 & 0.0650 & 0.1221 & 0.0461 & 0.4958 \\
\hline BR & 0.6809 & 1.0000 & 0.5891 & 0.1470 & 0.0602 & 0.5249 & 0.0014 & 0.3201 & 0.1873 & 0.5050 \\
\hline BA & 0.0537 & 0.2445 & 0.3922 & 0.0237 & 0.0253 & 0.0246 & 0.0029 & 0.0153 & 0.3879 & 0.1263 \\
\hline BP & 0.2459 & 0.2336 & 0.1812 & 0.0483 & 0.0314 & 0.1283 & 0.0018 & 0.1428 & 0.3594 & 0.2099 \\
\hline BD & 0.4227 & 0.8755 & 0.6474 & 0.3699 & 0.1687 & 1.0000 & 0.0053 & 0.4221 & 0.0548 & 0.2582 \\
\hline $\mathrm{CT}$ & 0.0323 & 0.5160 & 0.4562 & 0.0482 & 0.0841 & 0.3407 & 0.0061 & 0.2205 & 0.4190 & 0.0000 \\
\hline DG & 0.1344 & 0.2322 & 0.2334 & 0.1573 & 0.0728 & 0.3165 & 0.0068 & 0.3215 & 0.0755 & 0.0031 \\
\hline $\mathrm{HN}$ & 0.3037 & 0.4650 & 0.3107 & 0.2984 & 0.0621 & 0.6033 & 0.0022 & 0.3912 & 0.0680 & 0.0872 \\
\hline KL & 0.0836 & 0.1887 & 0.7017 & 0.0221 & 1.0000 & 0.5377 & 0.1949 & 0.7784 & 0.4791 & 0.0784 \\
\hline $\mathrm{KO}$ & 0.1822 & 0.3391 & 0.8842 & 0.1449 & 0.0963 & 0.7621 & 0.0038 & 0.4439 & 0.2369 & 0.0673 \\
\hline MK & 0.4204 & 0.1446 & 0.3566 & 0.0000 & 0.0802 & 0.2277 & 0.0210 & 0.3179 & 0.0186 & 0.1196 \\
\hline NK & 0.0662 & 0.3480 & 0.2279 & 0.0392 & 0.0483 & 0.4342 & 0.0011 & 0.4693 & 0.4343 & 0.0019 \\
\hline PL & 0.2366 & 0.1273 & 0.1199 & 0.0283 & 0.0421 & 0.0000 & 0.0138 & 0.0000 & 0.3148 & 0.0720 \\
\hline PV & 0.2113 & 0.1635 & 0.1473 & 0.0181 & 0.0000 & 0.0857 & 0.0011 & 0.0613 & 0.5244 & 0.1711 \\
\hline PŽ & 0.0310 & 0.0608 & 0.0000 & 0.0381 & 0.5604 & 0.1675 & 0.4166 & 0.3595 & 0.3192 & 0.1235 \\
\hline PG & 1.0000 & 0.3870 & 0.1812 & 0.2447 & 0.0359 & 0.6247 & 0.0000 & 0.4328 & 1.0000 & 0.6020 \\
\hline RO & 0.0976 & 0.0000 & 0.0554 & 0.0135 & 0.0942 & 0.0845 & 0.0083 & 0.0787 & 0.2077 & 0.6912 \\
\hline ŠA & 0.6304 & 0.0807 & 1.0000 & 0.0000 & 0.8965 & 0.4685 & 1.0000 & 1.0000 & 0.1491 & 0.6674 \\
\hline TV & 0.0244 & 0.4433 & 0.8799 & 1.0000 & 0.1057 & 0.6337 & 0.0064 & 0.3238 & 0.0000 & 1.0000 \\
\hline UL & 0.4001 & 0.6301 & 0.4685 & 0.0279 & 0.0652 & 0.5366 & 0.0040 & 0.3740 & 0.1231 & 0.5919 \\
\hline ŽB & 0.3431 & 0.4925 & 0.6153 & 0.1732 & 0.2378 & 0.1979 & 0.1110 & 0.2279 & 0.1780 & 0.5022 \\
\hline
\end{tabular}




\section{RESULTS}

Using a set of ten hierarchical road safety indicators in terms of final outcomes, the road users' behaviour and basic territory information, $21 \mathrm{mu}-$ nicipalities of Montenegro are evaluated via one composite index score. The relative weights for all of the three mentioned groups of indicators and the weights of each indicator in each group are obtained in terms of the grey relational degree, known as grey weights. Table 3 shows the final obtained relative grey weights of ten indicators and three indicator groups using multilayer and one-layer approaches. The grey relational coefficient obtained with Equation 4 can be observed as individual grey weights for each municipality, and the grey relational degree obtained with Equation 5 can be observed as joint weights. Individual weights in every group derived with both approaches range from 0.3333 to 1 . However, the average weights that represent the final weights of indicators if a multilayer approach is used, range from 0.4121 to 0.7202 in the behaviour group (I1-I4) and from 0.3813 to 0.7883 in the safer product group (I5-I8), whereas in the third group (I9 and I10) the weights are equal to 0.6349 . If the one-layer approach is performed, the grey weights range from 0.3858 to 0.6338 (I1-I10).

Whatever approach is used, the weights are additionally normalized with Equation 7 to satisfy the condition that the sum of weights in each group must be equal to one. Those weights can be used by policy makers for planning the future measures. The results show that in the overall safety score of Montenegro, the most influential group of indicators are those reflecting the behaviour because they received the highest grey weight score of 0.3713 . Taking into account that the data are not true rates but numbers of violations, the conclusion can be made that non-wearing a seatbelt represents one of the riskiest behaviours, with a grey weight of 0.2971 . In addition, experts have eventually introduced measures for each municipality according to its own grey weights instead of those based on the joint grey weights for the entire territory. In that case, based on the results from Table 3, the measures can be applied for wearing a seatbelt if they are applied to the entire territory. However, if using only the grey weights of PG (Podgorica), the experts can apply measures related to speeding if accessing only the road safety of that municipality. In summary, grey relational analysis can measure the relative importance among indicators, implying that those with higher grey weight values are more significant than those with lower grey weights.

To better understand and make comparison between the multilayer and one-layer results, the grey weight of each indicator is calculated in such a manner that all belong to one group and one layer. The results are shown at the bottom of Table 3. It can be concluded that the grey weights are smaller in this way but only because of the condition that the sum of all weights needs to be equal to one. The order of indicator significance remained the same. For example, among the behaviour indicators, non-wearing a seatbelt remained the riskiest. When calculated, the grey weights are further combined with the municipality performances to obtain one composite indicator and rank it.

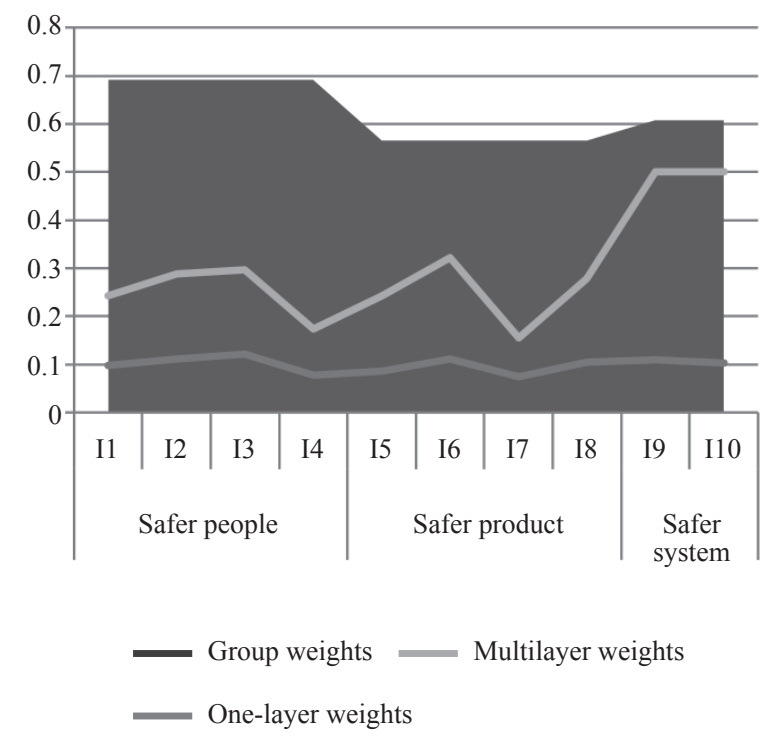

Figure 3 - Grey weights of indicators

Ranking is conducted in such a manner that the municipality with a higher safety level occupies a higher place. For Montenegro, Plav (PL) is ranked first, followed by Mojkovac (MK), Danilovgrad (DG) and Andrijevica (AN), as shown in Table 4. This result is not a surprise given that those municipalities are all small ones with low motorization levels and no main roads on their territories. The worst performing municipality is Podgorica (PG), which is one of the largest in Montenegro with a high motorization rate, population and road density. However, the overall scores and ranks for the municipalities are 


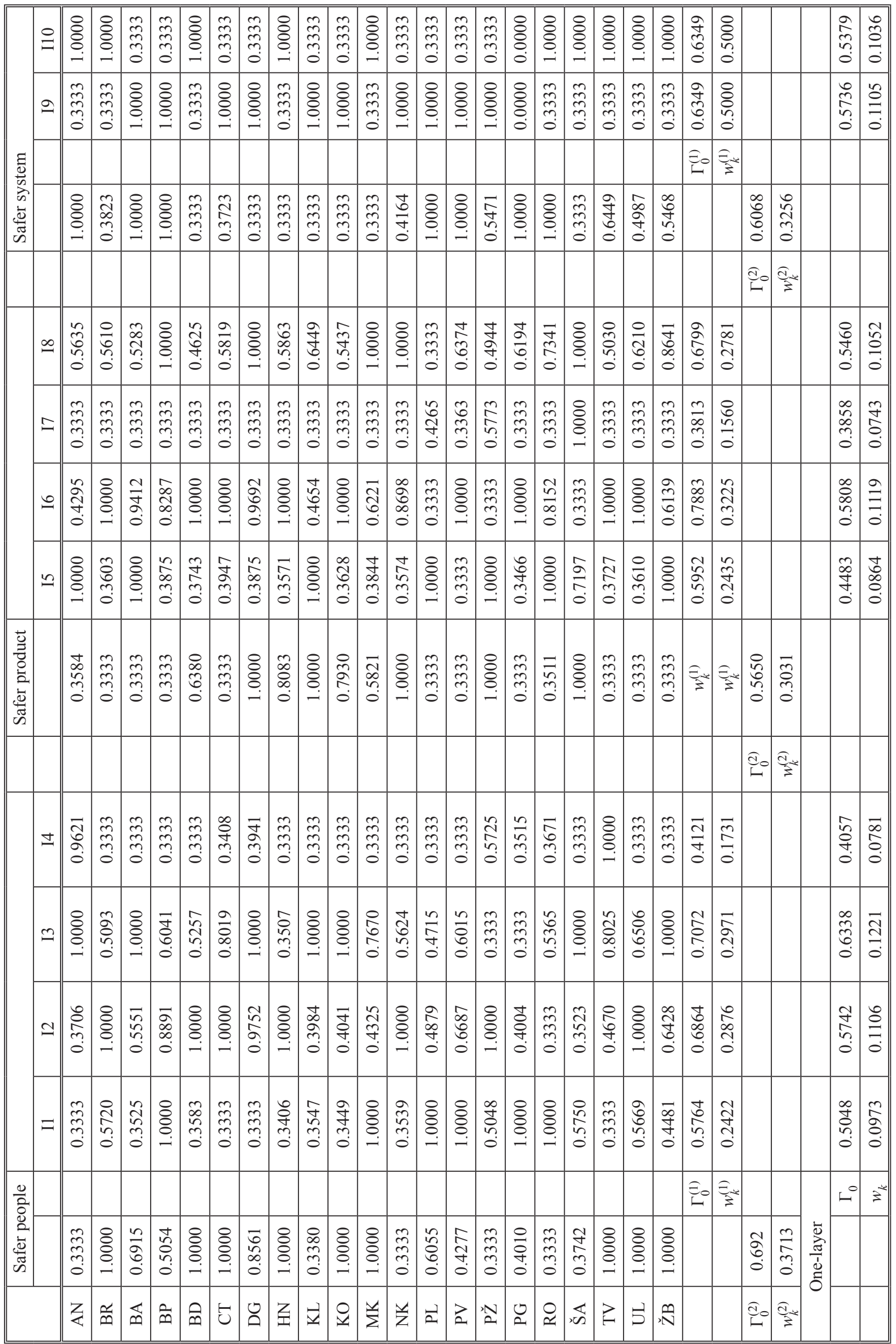


Table 4-Municipality scores

\begin{tabular}{|c|c|c|c|c|c|c|c|}
\hline & \multicolumn{3}{|c|}{ Two-layer weight analysis } & \multicolumn{3}{|c|}{ One-layer weight analysis } & \multirow{2}{*}{ DI } \\
\hline & GreyCI & $g C I$ & Rank & GreyCI & $g C I$ & Rank & \\
\hline $\mathrm{AN}$ & 0.1267 & 0.8733 & 4 & 0.1387 & 0.8613 & 3 & 0.0139 \\
\hline $\mathrm{BR}$ & 0.3463 & 0.6537 & 19 & 0.4310 & 0.5690 & 17 & 0.1489 \\
\hline BA & 0.1423 & 0.8577 & 5 & 0.1447 & 0.8553 & 4 & 0.0028 \\
\hline $\mathrm{BP}$ & 0.1718 & 0.8282 & 8 & 0.1693 & 0.8307 & 7 & -0.0030 \\
\hline $\mathrm{BD}$ & 0.2688 & 0.7312 & 16 & 0.4500 & 0.5500 & 18 & 0.3295 \\
\hline $\mathrm{CT}$ & 0.1615 & 0.8385 & 7 & 0.2350 & 0.7650 & 11 & 0.0961 \\
\hline DG & 0.1013 & 0.8987 & 3 & 0.1642 & 0.8358 & 6 & 0.0753 \\
\hline $\mathrm{HN}$ & 0.1885 & 0.8115 & 12 & 0.2730 & 0.7270 & 12 & 0.1162 \\
\hline KL & 0.3106 & 0.6894 & 17 & 0.4204 & 0.5796 & 16 & 0.1894 \\
\hline $\mathrm{KO}$ & 0.2405 & 0.7595 & 13 & 0.3482 & 0.6518 & 14 & 0.1652 \\
\hline MK & 0.0906 & 0.9094 & 2 & 0.1823 & 0.8177 & 8 & 0.1121 \\
\hline NK & 0.2520 & 0.7480 & 14 & 0.2262 & 0.7738 & 10 & -0.0333 \\
\hline PL & 0.0766 & 0.9234 & 1 & 0.1008 & 0.8992 & 1 & 0.0269 \\
\hline PV & 0.1539 & 0.8461 & 6 & 0.1498 & 0.8502 & 5 & -0.0048 \\
\hline $\mathrm{PŽ}$ & 0.1801 & 0.8199 & 10 & 0.1967 & 0.8033 & 9 & 0.0207 \\
\hline PG & 0.7323 & 0.2677 & 21 & 0.4727 & 0.5273 & 20 & -0.4923 \\
\hline RO & 0.1766 & 0.8234 & 9 & 0.1384 & 0.8616 & 2 & -0.0443 \\
\hline ŠA & 0.3822 & 0.6178 & 20 & 0.5873 & 0.4127 & 21 & 0.4970 \\
\hline TV & 0.3221 & 0.6779 & 18 & 0.4552 & 0.5448 & 19 & 0.2443 \\
\hline UL & 0.2540 & 0.7460 & 15 & 0.3482 & 0.6518 & 15 & 0.1445 \\
\hline ŽB & 0.1815 & 0.8185 & 11 & 0.3231 & 0.6769 & 13 & 0.2092 \\
\hline
\end{tabular}

slightly different when observing the indicators as one group in one layer versus three groups and two layers (see Table 4 and Figure 4).

To clearly illustrate the final aggregation of the composite index, a numerical example for one municipality (PG) is given. The example of calculating $g C I$ by the multilayer approach is shown as follows:

$\operatorname{GreyCI}(P G)=0.3713[0.2422 \cdot 1+0.2876 \cdot 0.3870+$

$+0.2971 \cdot 0.1812+0.1731 \cdot 0.2447]+0.3031$

$[0.2435 \cdot 0.0359+0.3225 \cdot 0.6247+0.1560 \cdot 0.0000+$

$+0.2781 \cdot 0.4328]+0.3256[0.500 \cdot 1.0000+0.500 \cdot 0.6020]=$

$=0.7323$

$g C I(P G)=1-$ GreyCI $=1-0.7323=0.2677$

The example of calculating the $\mathrm{gCI}$ of Podgorica (PG) municipality if a one-layer approach is used is given as follows:

$\operatorname{GreyCI}(P G)=0.0973 \cdot 1+0.1106 \cdot 0.3870+0.1221 \cdot 0.1812+$

$+0.0781 \cdot 0.2447+0.0864 \cdot 0.0359+0.1119 \cdot 0.6247+$

$+0.0743 \cdot 0.0000+0.1052 \cdot 0.4328+0.1105 \cdot 1.0000+$

$+0.1036 \cdot 0.6020=0.4727$

$g C I(P G)=1-$ GreyCI $=1-0.4727=0.5273$
In addition, to describe the differences between scores, the divergence index is calculated as follows:

$D I=\frac{g C I_{1}-g C I_{2}}{g C I_{2}}$

A larger divergence index indicates a larger difference between scores. For instance, the divergence index of Podgorica (PG) is -0.4923 which means that the score calculated with multilayer analysis deviates from the score calculated with one-level analysis by $49.23 \%$. To give a broad picture and to make comparisons between municipalities with similar background, grouping comparable municipalities and comparison among them within a specific group is conducted. Based on the $g C I$ score, regression equation is determined as:

$g C I^{*}=0.1480+0.1215 Y^{*}$

with $95 \%$ confidence limits and $P<0.001$. Municipalities are grouped into five classes presented in Table 5. To confirm that Equation 14 is statistically significant $(P=0.000<0.05)$, analysis of variance is 
Table 5 - Groups of municipalities

\begin{tabular}{|c|c|c|c|c|c|c|}
\hline Group & State of territory & Percentiles $\mathrm{P}^{*}$ & Probit $\mathrm{Y}^{*}$ & $g C I^{*}$ & Municipality & Best in class \\
\hline I & Very highly safe territory & 96.407 & 6.8 & 0.974 & - & \\
\hline II & Highly safe territory & 72.525 & 5.6 & 0.829 & $\begin{array}{c}\mathrm{PL}, \mathrm{MK}, \mathrm{DG}, \mathrm{AN}, \mathrm{BA}, \mathrm{PV}, \\
\mathrm{CT}\end{array}$ & PL \\
\hline III & Medium safe territory & 27.425 & 4.4 & 0.683 & $\begin{array}{c}\mathrm{BP}, \mathrm{RO}, \mathrm{PZ}, \mathrm{ZB}, \mathrm{HN}, \mathrm{KO} \\
\mathrm{NK}, \mathrm{UL}, \mathrm{BD}, \mathrm{KL}\end{array}$ & $\mathrm{BP}$ \\
\hline IV & Low safety territory & 3.593 & 3.2 & 0.537 & TV, BR, ŠA & TV \\
\hline $\mathrm{V}$ & Very low safety territory & $<3.593$ & $<3.2$ & $<0.537$ & PG & PG \\
\hline
\end{tabular}

conducted. The results are shown in Table 6 presenting acceptability and verification of the proposed grouping.

Table 6-Analysis of variance

\begin{tabular}{||l|c|c|c|c|c||}
\hline \hline & $\begin{array}{c}\text { Sum of } \\
\text { squares }\end{array}$ & df & $\begin{array}{c}\text { Mean } \\
\text { square }\end{array}$ & F & Sig. (P) \\
\hline \hline $\begin{array}{l}\text { Between } \\
\text { groups }\end{array}$ & 0.378 & 4 & 0.095 & 50.883 & 0.000 \\
\hline $\begin{array}{l}\text { Within } \\
\text { groups }\end{array}$ & 0.030 & 16 & 0.002 & & \\
\hline Total & 0.408 & 20 & & & \\
\hline
\end{tabular}

\section{DISCUSSION}

According to the proposed methodology for constructing one overall composite indicator, scores and ranking of territory can be obtained, as well as weights of the indicators included in the calculation. Road safety of a territory can be monitored annually and by analysing the assigned weights, the effects of implemented measures can be monitored. Comparison of the ranking based on the proposed methodology and the traditional rankings, Fatality Risk (FR, number of fatalities per 100,000 population) and Accident Risk (AR, number of accidents per 100,000 population) and RSDI value with the equal weighting method (weights of the indicators I1-I8 receive weights equal to 0.0833 and indicators I9-I10 receive the weight values of 0.1667 ) that is proposed by Al-Haji [9], is presented in order to grasp the insight among the rankings (see Figure 4).

Furthermore, the dashed lines in Figure 4 represent the deviation of the $g C I$ multilayer rank \pm 5 . It can be seen that relatively large deviations were recorded of the traditional rankings for municipalities BA, NK and PG. The ranks of municipalities regarding one-layer and multilayer are similar to some extent with the Parson`s correlation of 0.9039 (see Table 7). However, when compared to the traditional rankings, large variations between the ranks were observed when FR ranking is the matter and the similarities were recorded in comparison with AR ranking. The coefficient of correlation of the proposed grey multilayer method and the popularly and the usually used RSDI value has the highest harmony degree of 0.9571 . The following results

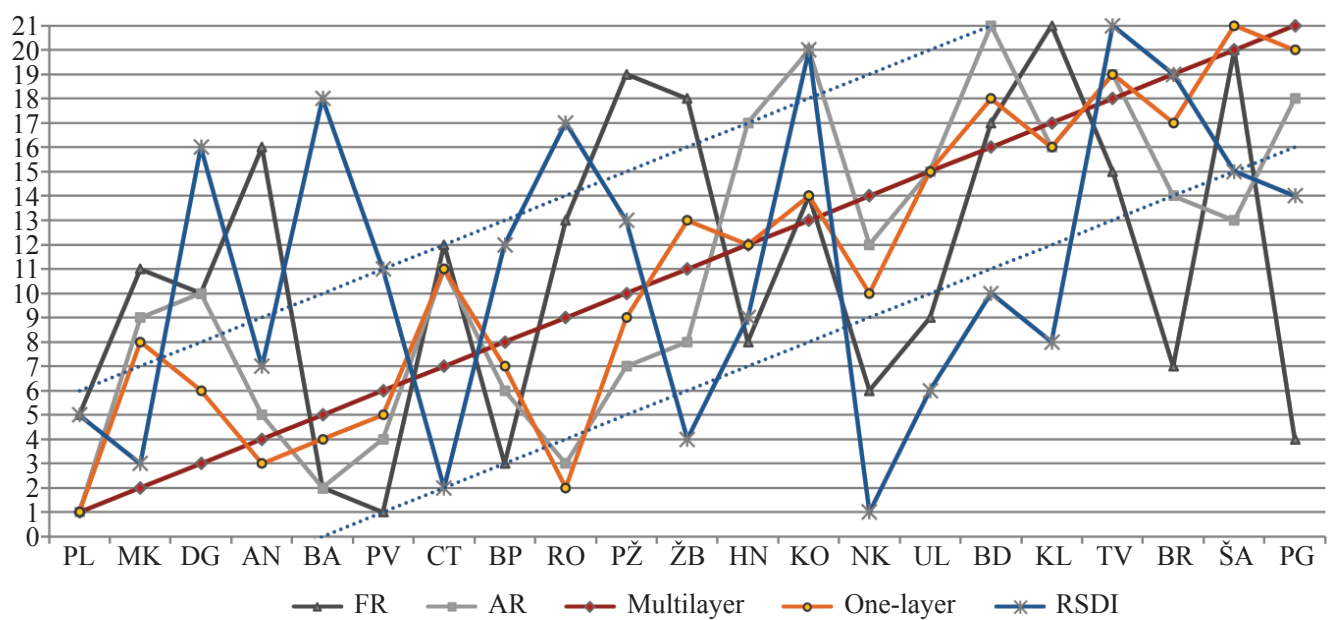

Figure 4-Comparison of ranking based on different analyses 
Table 7 - Correlations between rankings of each method

\begin{tabular}{||l|c|c|c|c|c||}
\hline \multirow{2}{*}{} & \multicolumn{2}{|c|}{ Traditional approach } & \multicolumn{2}{c||}{ Grey approach } \\
\cline { 2 - 3 } \cline { 5 - 6 } & FR ranking & AR ranking & RSDI & $\begin{array}{c}\text { One-layer } \\
\text { ranking }\end{array}$ & $\begin{array}{c}\text { Multilayer } \\
\text { ranking }\end{array}$ \\
\hline \hline FR ranking & 1 & 0.3221 & 0.4234 & 0.3766 & 0.2883 \\
\hline AR ranking & 0.3221 & 1 & 0.7675 & 0.8649 & 0.7571 \\
\hline RSDI & 0.4234 & 0.7675 & 1 & 0.9455 & 0.9571 \\
\hline One-layer ranking & 0.3766 & 0.8649 & 0.9455 & 1 & 0.9039 \\
\hline Multilayer ranking & 0.2883 & 0.7571 & 0.9571 & 0.9039 & 1 \\
\hline \hline
\end{tabular}

Note: Correlations are significant at $p<.05000 \mathrm{~N}=21$

justified the intention of designing the GRA-based road safety performance index constructed of different variables at different layers.

When grouping of municipalities is conducted (see Table 5), five classes are formed. Most municipalities were described as territories with medium road safety level with BP as benchmark. There are no territories described as very highly safe and only one municipality in the last group is $\mathrm{PG}$, which is at the bottom of all ranks and it is characterized by a large number of road accidents and road fatalities.

\section{CONCLUSION}

Evaluation of road safety is the core of road safety management, and to prevent traffic accidents an understanding of the factors that cause them is essential. Currently, road safety experts show great interest in finding one fair approach to evaluate and compare road safety situations on different territories. Many tools and statistical and mathematical methods were used to accomplish that goal, but few have used grey relational analysis. Because the GRA is successfully applicable for a smaller number of entities and because many of the factors causing traffic accidents are characterized by incomplete, imperfect or complex information, we proposed the use of GRA to calculate the weights for aggregation of one overall solid road safety composite indicator.

The main contribution of this paper is a method for calculating the grey weights of both one-layer and multilayer sets of indicators. First, the indicators should be selected and categorized. There is no unique number of layers and categories, which is an advantage and a deficiency because absolute freedom is given to the researcher in choosing data for a particular subject of research. To analyse the influence of the selected factors on traffic accidents, the relative significance of each is determined with the grey relational degree. A numerical example in this paper is applied to a case study of Montenegro with the most used indicator categories: behaviour, exposure and system indicators. The Montenegro behaviour-related indicators used in this paper are violations related to speeding, drinking and driving, non-wearing a seatbelt and phone use while driving. The exposure indicators used are the numbers of fatalities per population and vehicles as well as the numbers of accidents with fatalities per population and vehicles. Road density and motorization level are used because they are related to the system indicators. Data were normalized and the relation degree was calculated representing the grey weights for aggregation. Generally, these weights can be useful for policymakers, because they can show leaks in road safety chain and the places where additional effort is needed. Finally, the composite indicator is calculated for a one-layer indicator framework and a multilayer indicator framework. The results show that behaviour-related indicators received the highest grey weights, highlighting that it is the most important issue that experts should address in the future efforts and emphasis that non-wearing a seatbelt while driving represents a behaviour particularly problematic when observing the whole territory. In addition, the proposed methodology gives policy-makers an opportunity to address road safety in micro level, observing only one territory. In that matter, by high weights assigned to speed indicator in PG municipality, for example, the experts may conduct measures and campaigns in order to increase the number of people who respect speed limit.

Based on the results the rank of the territories can be established. Different ranking positions occur when different numbers of layers are used. However, the order of significance of each indicator remains the same. The correlations between the rankings 
obtained by the different methods were observed. The analysis shows that the ranking of territories of road safety based on the composite indicators and traditional rankings are not identical. The ranking derived with the proposed methodology received the highest correlation value when compared with the RSDI ranking, which is a similar type of analysis.

Given that the GRA is normalization-based methodology, the calculated results might vary based on the type of normalization, which is the largest shortcoming of this method. Therefore, further research should investigate the normalization method that best fits the data representing road safety. Because road safety data represent a key issue in the construction of a composite indicator, sensitive analysis should be implemented, and the need exists to define the standardized categories of indicators as well as the indicators themselves that can best describe the level of road safety of territories and are also applicable to underdeveloped countries with a lack of data.

\author{
MIRJANA GRDINIĆ-RAKONJAC, \\ mast. inž. saobraćaja ${ }^{1}$ \\ E-mail: grdinicm@ucg.ac.me; \\ Doc. Dr BORIS ANTIĆ 2 \\ E-mail: b.antic@sf.bg.ac.rs; \\ Doc. DR DALIBOR PES̆IĆ 2 \\ E-mail: d.pesic@sf.bg.ac.rs; \\ Prof. Dr VLADIMIR PAJKOVIĆ ${ }^{1}$ \\ E-mail: pajkovic@ucg.ac.me; \\ ${ }^{1}$ Univerzitet Crna Gora, Mašinski fakultet \\ Džordža Vašingtona 1, 81000 Podgorica, Crna Gora \\ ${ }^{2}$ Univerzitet u Beogradu, Saobraćajni fakultet \\ Vojvode Stepe 305, 11000 Beograd, Srbija
}

\section{KREIRANJE KOMPOZITNOG INDIKATORA BEZBEDNOSTI SAOBRAĆAJA KORIŠĆENJEM SIVE RELACIONE ANALIZE}

\section{REZIME}

Agregatni indeks (indikator) bezbednosti saobraćaja predstavlja popularni koncept ocene stanja i poređenja nivoa bezbednosti na određenim teritorijama/entitetima. U ovom radu je predstavljena nova, inovativna metodologija otežavanja (ponderisanja) indikatora pomoću sive relacione analize. Deset hijerarhijskih indikatora bezbednosti saobraćaja je grupisano u dva nivoa i tri kategorije koje se odnose na ponašanje vozača, bezbednost vožnje i sistem bezbednosti. Sivi težinski koeficijenti su dodeljeni svim kategorisanim indikatorima na svim nivoima a zatim je, aditivnom agregacijom, izračunavan sivi kompozitni indeks bezbednosti saobraćaja za svaki entitet (21 posmatranu teritoriju). Izložena metodologija može, dodelom relativno velikih težinskih koeficijenata, da ukaže donosiocima odluka na domene bezbednosti koje bi trebalo unaprediti. Rezultati jasno oslikavaju efektivnost primene velikog broja hijerarhijski raspoređenih indikatora.

\section{KLJUČNE REC̆I}

bezbednost saobraćaja; kompozitni indikator; metodologija za otežavanje koeficijenata; siva relaciona analiza; sivi težinski koeficijenti; studija slučaja.

\section{REFERENCES}

[1] World Health Organization. Global status report on road safety 2018. Available from: https://www.who.int/publications/i/item/global-status-report-on-road-safety-2018

[2] European Council. European Council conclusions on road safety. Available from: http://data.consilium.europa.eu/doc/document/ST-9994-2017-INIT/en/pdf

[3] World Health Organization. Decade of Action for Road Safety 2011-2020. Saving millions of lives. 2011. Available from: http://www.who.int/violence_injury_prevention/publications/road_traffic/saving_millions_lives_ en.pdf?ua $=1$

[4] United Nations. Transforming Our World: The 2030 Agenda for Sustainable Development. Available from: https://sustainabledevelopment.un.org/post2015/transformingourworld

[5] Ministry of the Interior. Strategy for improvement of road traffic safety 2010-2019. Podgorica; 2009.

[6] Government of Montenegro. Action plan for Strategy for improvement of road traffic safety implementation. Podgorica; 2011.

[7] European Commission. Road Safety in the European Union - Trends, statistics and main challenges. Available from: https://ec.europa.eu/transport/road_safety/ sites/roadsafety/files/vademecum_2018.pdf

[8] European Transport Safety Council. 2010 Road Safety Target Outcome: 100,000 fewer deaths since 2001. ETSC. $5^{\text {th }}$ Road Safety PIN Report, 2011.

[9] Al-Haji G. Development of an International Index to Measure Road Safety Performance. Linköping Studies in Science and Technology, Norrköping, Sweden; 2005.

[10] Al-Haji G. Road Safety Development Index (RSDI) Theory, Philosophy and Practice. PhD thesis No. 1100. Department of Science and Technology, Linköping University, Sweden; 2007.

[11] Hakkert AS, Gitelman V, Vis MA (ed.). Road Safety Performance Indicators: Theory. Deliverable D3.6 of the EU FP6 Project SafetyNet; 2007.

[12] Wegman F, Commandeur J, Doveh E, Eksler V. SUNflowerNext: Towards A Composite Road Safety Performance Index. SWOV, Leidschendam; 2008.

[13] Hermans E, Van den Bossche F, Wets G. Combining road safety information in a performance index. Accident Analysis and Prevention. 2008;40: 1337-1344. DOI: 10.1016/j.aap.2008.02.004

[14] European Commission. Handbook of constructing composite indicators. Methodology and user quide. Paris; 2008. Available from: https://www.oecd.org/ sdd/42495745.pdf 
[15] Wegman F, Oppe S, Benchmarking road safety performances of countries. Safety Science. 2010;48: 12031211. DOI: $10.1016 /$ j.ssci.2010.02.003

[16] Gitelman V, Doveh E, Hakkert S. Designing a composite indicator for road safety. Safety Science. 2010;48: 1212 1224. DOI: 10.1016/j.ssci.2010.01.011

[17] Pešić D, Vujanić M, Lipovac K, Antić B. New method for benchmarking traffic safety level for the territory. Transport. 2013;28(1): 69-80. DOI: 10.3846/16484142.2013.781539

[18] Kukić D, Lipovac K, Pešić D, Rosić M. The differences of road safety performance of countries based on outcome indicators. Safety Science. 2016;89: 279-287. DOI: 10.1016/j.ssci.2016.07.005

[19] Tešić M, Hermans E, Lipovac K, Pešić, D. Identifying the most significant indicators of the total road safety performance index. Accident Analysis and Prevention. 2008;113: 263-278. DOI: 10.1016/ j.aap.2018.02.003

[20] Lu M, Wevers K. Application of grey relational analysis for evaluating road traffic safety measures: Advanced driver assistance systems against infrastructure redesign. IET Intelligent Transport Systems. 2007;1(1): 3-14. DOI: 10.1049/iet-its-20060022

[21] Ma Z, Shao C, Ma S, Ye Z. Constructing road safety performance indicators using Fuzzy Delphi Method and Grey Delphi Method. Expert Systems with Applications. 2011;38: 1509-1514. DOI: 10.1016/j.eswa.2010.07.062

[22] René SH, Becker U, Manz H. Grey system theory time series prediction applied in road traffic safety in Germany. IFAC-PapersOnLine. 2016;49(3): 231-236. DOI: 10.1016/j.ifacol.2016.07.039
[23] Liu Y, Huang X, Duan J, Zhang H. The assessment of traffic accident risk based on grey relational analysis and fuzzy comprehensive evaluation method. Nat Hazard. 2017;88: 1409-1422. DOI: 10.1007/s11069-017-2923-2

[24] Deng J. Introduction to grey system theory. The Journal of Grey System. 1989;1(1): 1-24.

[25] Chen F, Wu J, Chen X, Wang J, Wang D. Benchmarking road safety performance: Identifying a meaningful reference (best-in-class). Accident Analysis and Prevention. 2016;86: 76-89. DOI: 10.1016/j.aap.2015.10.018

[26] SafetyNet. State-of-the-art Report on Road Safety Performance Indicators. Work Package 3, Integrated Project; 2005. Available from: https://erso.swov.nl/safetynet/ fixed/WP3/Deliverable $\% 20 w p \% 203.1 \% 20$ state $\% 20$ of $\% 20$ the $\% 20$ art.pdf

[27] IRTAD - International Transport Forum. Road Safety Annual Report 2014. Available from: http://www.oecd-ilibrary.org/transport/road-safety-annual-report-2014 irtad-2014-en

[28] Antić B, Grdinić M, Pešić D. Pajković V. Benchmarking of the road safety performance among the regions by using DEA. Transportation Research Procedia. 2020;45: 78-86. DOI: 10.1016/j.trpro.2020.02.065

[29] Cheng X, Wu Y, Ning P, Cheng P, Schwebel CD, Hu G. Comparing road safety performance across countries: Do data source and type of mortality indicator matter? Accident Analysis and Prevention. 2018;121: 129-133. DOI: 10.1016/j.aap.2018.09.012

[30] European Commission. 2018 road safety statistics: What is behind the figures? Available from: https://ec.europa. eu/commission/presscorner/detail/en/MEMO_19_1990 